\title{
57. SULFUR ISOTOPIC VARIATIONS IN NODULAR AND DISSEMINATED PYRITE: HOLE 603B ${ }^{1}$
}

\author{
Linda M. Bonnell and Thomas F. Anderson, University of Illinois, Urbana ${ }^{2}$
}

\begin{abstract}
Analyses of modern marine sediments have suggested that availability and type of organic matter, sedimentation rate, and openness of the sulfate system influence the degree of isotopic fractionation between seawater sulfate and sedimentary iron sulfides. Isotopic studies of ancient sulfides should, therefore, provide insights into conditions of deposition and early diagenesis. Analysis of $\delta^{34} \mathrm{~S}$ of disseminated pyrite from Cretaceous sediments of Hole 603B yielded fractionations relative to coeval seawater sulfate ranging from 40 to $55 \%$, which are within the range for modern oxic marine sediments reported by others. Sulfur/carbon ratios are similar to those found from modern marine sediments and suggest that disseminated pyrite formation was dependent upon available organic carbon. These results imply that depositional and early diagenetic conditions during the Cretaceous in Hole $603 \mathrm{~B}$ were similar to those occurring in initially oxic marine environments today.

Macroscopic (nodular) pyrite from Hole $603 \mathrm{~B}$ is isotopically variable $\left(\delta^{34} \mathrm{~S}\right.$ values $=-48$ to $+33 \%$ ), but generally more positive than disseminated pyrite. The isotopic evidence suggests that macroscopic pyrite formed during late stages of sulfate reduction in a system closed with respect to sulfate. However, detailed analyses of large pyrite nodules did not yield a consistent pattern of isotopic variation from center to rim.
\end{abstract}

\section{INTRODUCTION}

The degree of bacterial fractionation between seawater sulfate and pyrite sulfur in modern sediments depends to some extent upon the reactivity of available organic matter and the length of time it is exposed to oxidizing conditions at the sediment/water interface (Goldhaber and Kaplan, 1974). Thus, the isotopic composition of disseminated pyrite in sediments can be used as an indicator of conditions of deposition. In addition, the ratio of pyritic sulfur to organic carbon may indicate whether the sediments were deposited in an oxic or anoxic environment (Leventhal, 1983; Berner and Raiswell, 1983; Berner, 1984).

This study examines disseminated and nodular pyrite found in relatively organic-carbon-rich rocks of Valanginian to Santonian age from Hole 603B in an attempt to assess the depositional and early diagenetic conditions. Dark, relatively organic-carbon-rich beds in the interbedded black and green mudstone unit are characterized by abundant disseminated pyrite (averaging $1.6 \%$ pyrite) and several large, volumetrically significant pyrite nodules and layers. Previous sulfur isotopic analyses of sulfide phases from DSDP sites have been concerned primarily with macroscopic pyrite in sediments and basalts (Krouse et at., 1977; Puchelt and Hubberton, 1980). Macroscopic pyrite is possibly a late diagenetic product, whereas disseminated pyrite forms relatively rapidly below the sediment/water interface (Goldhaber et al., 1977; Berner, 1980; Westrich, 1983). Therefore, the isotopic

\footnotetext{
${ }^{1}$ van Hinte, J. E., Wise, S. W., Jr., et al., Init. Repts. DSDP, 93: Washington (U.S. Govt. Printing Office).

2 Address: University of Illinois, Department of Geology, 1301 w. Green St., Urbana, IL 61801 .
}

composition of macroscopic pyrite could reflect a variety of conditions of formation and not be indicative of the immediate environment of sediment deposition and early diagenesis. In an attempt to detect possible isotopic differences between macroscopic and disseminated pyrite, large pyrite nodules and disseminated pyrite in immediately adjacent rocks were analyzed. In addition, detailed analyses of large pyrite nodules were conducted to detect isotopic variations possibly associated with nodule growth history.

\section{SAMPLE DESCRIPTION AND ANALYTICAL METHODS}

Pyrite nodules and layers occur throughout the cores from Hole $603 \mathrm{~B}$, predominantly in organic-carbon-rich shales and limestones and less commonly in siltstones and fine sandstones. The nodules examined range in diameter from $30 \mathrm{~mm}$ to $3 \mathrm{~cm}$ and contain from 75 to $100 \%$ pyrite, with the remainder consisting of carbonate. The large nodules are characterized by massive interiors and euhedral (mostly cubes and pyritohedra) crusts (Fig. 1). Using a microslice saw, each pyrite layer examined was sliced into a series of 2 -mm slabs oriented parallel to bedding direction. A sample from each slab was analyzed to detect vertical changes in the layer. Large pyrite nodules, whose orientation was unknown, were sliced into 2 -mm-thick slabs and sampled from center to rim across a single slab (Fig. 2).

Whole small pyrite nodules, as well as rock containing disseminated pyrite, were crushed to a fine powder and dried prior to chemical analysis. Disseminated pyrite was extracted from 18 dark gray to black mudstones and marls ranging in age from Valanginian to Santonian (Table 1). Rock samples were treated with hot $4.8 M \mathrm{HCl}$ to remove pore water sulfate and acid-soluble intermediate sulfides (mackinawite and greigite) if present. None of the samples yielded measurable amounts of acid-soluble sulfides. Pyritic sulfur was extracted from the acid-treated sediment and the crushed massive pyrite using the LAH reduction method described by Westgate and Anderson (1982). The samples were treated with lithium tetrahydridoaluminate (LAH) and tetrahydrofuran (THF) to decouple iron and sulfur. Addition of $\mathrm{H}_{2} \mathrm{O}$ and $\mathrm{HCl}$ resulted in production of $\mathrm{H}_{2} \mathrm{~S}$, which was converted to cadmium sulfide in cadmium acetate solution. Cadmium sulfide was converted to silver sulfide and combusted with cupric oxide to produce $\mathrm{SO}_{2}$, which was measured on a MAT 250 mass spectrometer. 


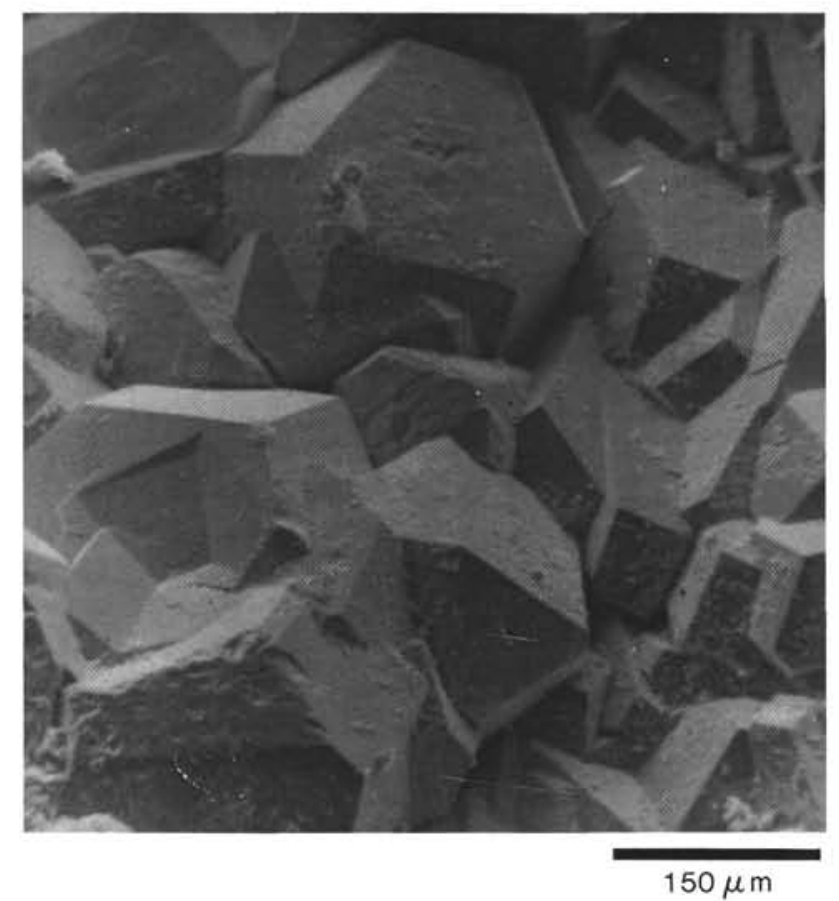

Figure 1. Scanning electron micrograph of euhedral pyrite on the rim of pyrite nodule from Sample 603B-65-1, $17 \mathrm{~cm}$.

\section{RESULTS}

Sulfur isotopic data are given in the usual notation:

$$
\delta^{34} \mathrm{~S}=\left[\frac{{ }^{34} \mathrm{~S} /{ }^{32} \mathrm{~S}_{\text {sample }}}{{ }^{34} \mathrm{~S} /{ }^{32} \mathrm{~S}_{\text {standard }}}\right]-1 \times 1000
$$

Canyon Diablo Troilite is the reporting standard. The black mudstones and marls of Hole 603B contain 0.6 to $2.9 \%$ disseminated pyritic sulfur; rock surrounding a pyrite nodule containing a much larger amount of pyrite (6.9 to $11.4 \%$ ). The $\delta^{34} \mathrm{~S}$ values of all disseminated pyrite varies from -19 to $-37 \%$ with most between -24 and $-37 \%$ (Table 1).

The $\delta^{34} \mathrm{~S}$ value of pyrite nodules and layers varies widely from -49 to $+33 \%$ (Table 2 ). Vertical isotopic variations of 2 to $6 \%$ were found in the two pyrite layers examined. Large pyrite nodules showed up to a $17 \%$ difference in $\delta^{34} \mathrm{~S}$ from nodule center to rim (Fig. 3). In all cases, the $\delta^{34} \mathrm{~S}$ of the host rock is more negative than the accompanying nodules.

\section{DISCUSSION}

\section{Disseminated Pyrite}

Sulfate reduction in marine sediments is mediated by anaerobic bacteria. As a consequence, sulfate reduction occurs only in anoxic environments. These conditions are commonly found below the sediment/water interface in organic-carbon-rich sediments where aerobic decomposition has consumed all available oxygen. The zone of sulfate reduction can range from open to closed with respect to diffusion of seawater sulfate from overlying seawater.

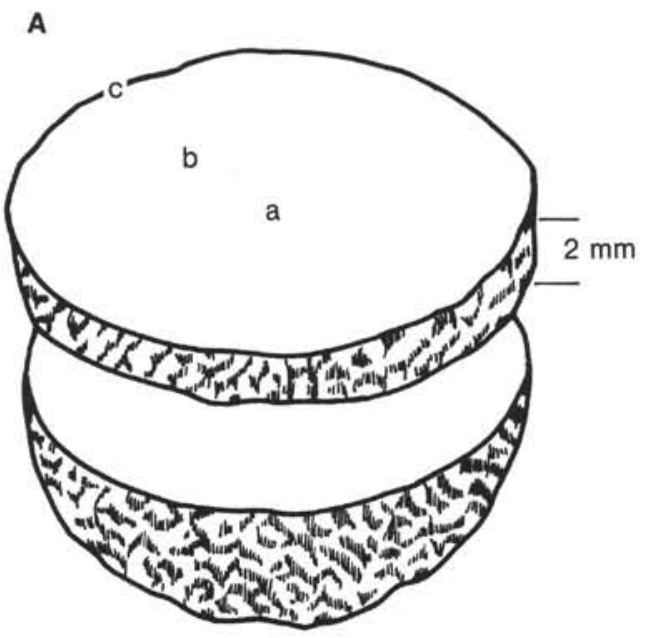

B

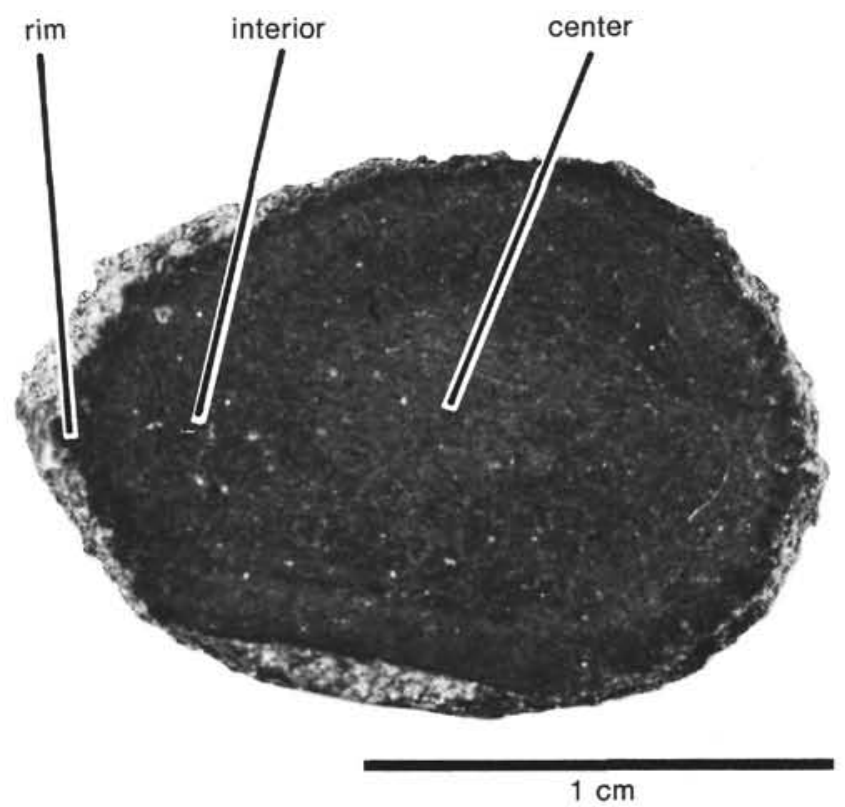

Figure 2. A. The sampling pattern for large pyrite nodules: $a=$ center, $\mathrm{b}=$ interior, $\mathrm{c}=$ rim. B. Cross-sectional view of pyrite nodule from Sample 603B-46-4, $14 \mathrm{~cm}$ showing approximate locations of samples for isotopic analyses.

The extent of isotopic fractionation from seawater reflects the degree of isolation of the sulfate-reduction process from the water column. If the environment is closed with respect to sulfate and all sulfate is consumed as the reaction goes to completion, then the resulting total sulfide will have the same isotopic composition as the original sulfate (Goldhaber and Kaplan, 1974). Laterforming sulfides will exhibit more positive isotopic values than those that formed earlier. Conversely, if diffusion and bioturbation allows for continuous mixing between seawater and pore water sulfate, sulfate reduction will occur with an essentially infinite sulfate reservoir. Under these conditions, the isotopic composition of sulfide produced will reflect more closely biologic fractionation that occurs during the sulfate-reduction process. 
Table $1 . \delta^{34} \mathrm{~S}$ value of disseminated pyrite from organic carbonrich mudstones and marls, Hole 603B.

\begin{tabular}{lclcc}
\hline $\begin{array}{c}\text { Core-Section } \\
\text { (interval in cm) }\end{array}$ & $\begin{array}{c}\text { Sub-bottom } \\
\text { depth }(\mathrm{m})\end{array}$ & \multicolumn{1}{c}{ Age } & $\begin{array}{c}\delta^{34} \mathrm{~S} \\
(\% 0)\end{array}$ & $\begin{array}{c}\text { Pyrite } \\
(\%)\end{array}$ \\
\hline $28, \mathrm{CC}, 05$ & 1080.00 & Santonian & -34.4 & 1.12 \\
$32-1,61$ & 1110.11 & Coniacian & -37.1 & 1.82 \\
$34-2,35$ & 1129.38 & Cenomanian & -28.6 & $6.95^{\mathrm{a}}$ \\
$36-1,118$ & 1146.68 & Cenomanian & -26.8 & 0.59 \\
$44-3,53$ & 1217.93 & late Aptian & -31.4 & 1.93 \\
$53-5,28$ & 1307.08 & Barremian & -34.2 & 2.25 \\
$53-5,32$ & 1307.12 & Barremian & -24.1 & 1.35 \\
$58-4,102$ & 1354.32 & early Barremian & -36.2 & 2.04 \\
$63-5,128$ & 1403.48 & late Hauterivian & -31.0 & 1.69 \\
$65-4,107$ & 1420.27 & m Hauterivian & -24.5 & 0.85 \\
$66-2,107$ & 1426.27 & m Hauterivian & -2.8 & $1.10^{\mathrm{a}, \mathrm{b}}$ \\
$66-3,35$ & 1427.05 & m Hauterivian & -36.1 & 2.85 \\
$67-4,126$ & 1438.46 & m Hauterivian & -31.5 & $10.40^{\mathrm{a}}$ \\
$67-4,126$ & 1438.46 & m Hauterivian & -32.0 & 6.08 \\
$75-2,48$ & 1503.88 & Valanginian & -18.8 & 1.26 \\
$75-2,61$ & 1504.01 & Valanginian & -25.6 & 1.40 \\
$75-2,114$ & 1504.54 & Valaginian & -31.7 & $11.40^{\mathrm{a}}$ \\
$75-2,115$ & 1504.55 & Valanginian & -33.1 & 2.33 \\
\hline
\end{tabular}

a Rock immediately adjacent to a pyrite nodule.

b Light gray silty sandstone.

Table 2. $\delta^{34}$ S values $(\%)$ of macroscopic pyrite, Hole 603B.

\begin{tabular}{|c|c|c|c|c|c|}
\hline $\begin{array}{c}\text { Core-Section } \\
\text { (interval in cm) }\end{array}$ & $\begin{array}{l}\text { Sub-bottom } \\
\text { depth }(m)\end{array}$ & Age & Description & $\begin{array}{c}\delta^{344} S \\
\text { nodule }\end{array}$ & $\begin{array}{l}\delta^{34} \mathrm{~S} \\
\text { rock }\end{array}$ \\
\hline $34-2,35$ & 1129.30 & Cenomanian & Pyrite layer & -13.1 & -28.6 \\
\hline $44-3,52$ & 1217.92 & Aptian & $\begin{array}{l}\text { Layer-rim } \\
\quad \text { center } \\
\text { interior } \\
\quad \text { rim }\end{array}$ & $\begin{array}{l}-41.3 \\
-46.4 \\
-48.6 \\
-47.8\end{array}$ & \\
\hline $46-4,14$ & 1238.24 & Aptian & $\begin{array}{l}\text { Nodule-rim } \\
\text { interior } \\
\text { center }\end{array}$ & $\begin{array}{l}-28.4 \\
-39.1 \\
-34.8\end{array}$ & \\
\hline $65-1,17$ & 1414.87 & m Hauterivian & $\begin{array}{l}\begin{array}{l}\text { Layer-rim } \\
\text { interior }\end{array} \\
\text { Rim }^{\mathrm{a}}\end{array}$ & $\begin{array}{l}-32.7 \\
-27.8 \\
-26.6\end{array}$ & \\
\hline $66-2,107$ & 1426.27 & m Hauterivian & $\begin{array}{l}\text { Nodule-rim } \\
\text { interior } \\
\text { center }\end{array}$ & $\begin{array}{l}+15.1 \\
+25.3 \\
+32.1\end{array}$ & -2.8 \\
\hline $67-4,126$ & 1438.46 & m Hauterivian & Nodule & -13.6 & -31.5 \\
\hline $75-2,114$ & 1504.54 & Valanginian & Nodule & +33.5 & -31.7 \\
\hline
\end{tabular}

a Includes some disseminated pyrite from adjacent rock.

Laboratory studies (Harrison and Thode, 1958; Kaplan and Rittenberg, 1964) and observations on marine sediments (Goldhaber and Kaplan, 1975; 1980) have shown that the extent of isotopic fractionation between reduced sulfur species and dissolved sulfate $\left(\Delta^{34} S\right)$ is inversely proportional to the rate of bacterial reduction. The rate of sulfate reduction $(\mathrm{R})$ depends on the reactivity of organic matter (Berner, 1978; Westrich and Berner, 1984), which depends on the type of organic matter (Goldhaber and Kaplan, 1974) and which decreases with exposure to aerobic oxidation at the sediment/water interface (Berner, 1974; Goldhaber and Kaplan, 1975). Therefore, the rate of sulfate reduction should be directly proportional to the rate of burial of metabolizable organic matter, hence the rate of sedimentation $(\omega)$ (Goldhaber and Kaplan, 1975), and fractionation should increase as sedimentation rate decreases. Maynard (1980) has derived a mathematical expression for this relationship (in the form $\Delta^{34} \mathrm{~S}=a+b \log \omega$ ) from the functional relationships between $\Delta^{34} \mathrm{~S}$ and $\mathrm{R}$ and between $\mathrm{R}$ and $\omega$.

The $\delta^{34} \mathrm{~S}$ values of disseminated pyrite in organic-carbon-rich Cretaceous rocks of Hole $603 \mathrm{~B}$ yield $\Delta^{34} \mathrm{~S}$ val-
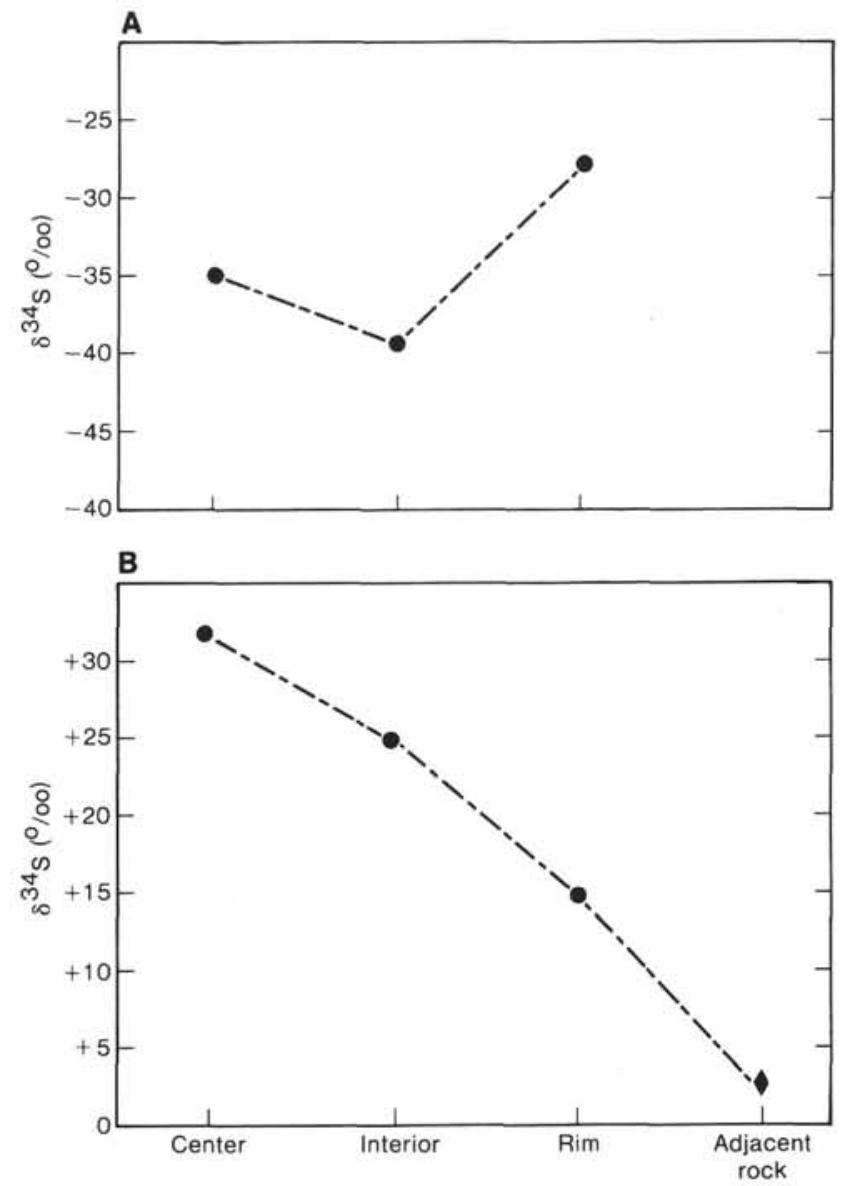

Figure 3. $\delta^{34} \mathrm{~S}$ variation across pyrite nodule from (A) Sample 603B$46-4,14 \mathrm{~cm}$; (B) Sample 603B-66-2, $107 \mathrm{~cm}$ from center of nodule to disseminated pyrite in immediately adjacent rock.

ues relative to mid-Cretaceous seawater sulfate $(+16 \%$, Claypool et al., 1980) in the range -40 to $-55 \%$. These fractionations are comparable to the results on pyrite from the Sharon Springs Member of the Pierre Shale (Campanian) by Gautier et al. (1984). The fractionations for Hole 603B rocks are also similar to the range of "instantaneous" $\Delta^{34} \mathrm{~S}$ values $(-40$ to $-60 \%)$ calculated for modern marine sediments in the basins of the Gulf of California and off Southern California (Goldhaber and Kaplan, 1975, 1980). This comparison suggests that sulfate reduction and pyrite formation in the Cretaceous rocks from Hole 603B occurred under opensystem conditions near the sediment/water interface. Open-system conditions are consistent with the relatively low sedimentation rates estimated for these rocks (Site 603 chapter, this volume).

Interestingly, however, the sedimentation rates for the Cretaceous Hole 603B rocks would "predict" much more negative fractionations from the relationship between $\Delta^{34} S$ and $\omega$ derived by Maynard (1980). Maynard (1980) observed that fractionations in modern marine sediments of relatively low sedimentation rates also deviated systematically from predicted values and suggested that fractionation approaches a limit at slow sedimentation rates. Of course, bacterial isotope fractionation is ultimately constrained by equilibrium isotope fractionation between 
dissolved sulfide species and sulfate $(-70$ to $-80 \% 0$ at $25^{\circ} \mathrm{C}$, Sakai, 1968), but maximum fractionation in early diagenesis seldom approaches this limit. Rather, it appears that one or both of the independently determined and well-documented relationships between $\Delta^{34} S$ and $R$ and between $\mathrm{R}$ and $\omega$ (which comprise the $\Delta^{34} \mathrm{~S}-\omega$ expression) cannot be applied to a variety of modern and ancient marine sediments that accumulated at low rates. More sulfur isotopic data are needed on modern sediments where sulfate reduction and sedimentation rates are known in order to resolve this important problem.

Recent studies of modern sediments have shown that under noneuxinic ("normal marine") conditions, pyritic sulfur is linearly correlated to organic carbon with a zero intercept (Sweeney, 1972; Leventhal, 1983). The positive correlation between sulfur and organic carbon indicates that pyrite formation is dependent upon available reactive organic matter. Under euxinic conditions (such as the Black Sea) S/C ratios are higher than in "normal marine" settings, and the $\mathrm{S}-\mathrm{C}$ covariance line has a positive S-intercept (Leventhal, 1983). This type of relationship between pyritic sulfur and organic carbon has been observed in black shales from DSDP Hole 530 in the South Atlantic (Bonnell and Anderson, 1984; in preparation), as well as in Cretaceous shales from Colorado and Kansas (Gautier et al., 1984). As shown in Figure 4, most sulfur-carbon data from Hole 603B cluster near the "normal marine" line as defined by Sweeney (1972). Nodule host sediments are anomalous because of their extremely high pyritic sulfur contents (up to $11 \%$ ) and do not lie near the "normal marine" line. The S-C plot of Cretaceous organic-carbon-rich sediments from Hole 603B suggests that pyrite formation was limited by the availability of organic carbon and occurred under oxygenated bottom waters.

\section{Macroscopic Pyrite}

Pyrite nodule formation may begin subsequent to or contemporaneous with the formation of framboidal pyrite below the sediment/water interface, but also may continue after sediment burial. Work by Kaplan et al. (1963) and Berner (1982) has shown that sulfate concentration in pore water decreases systematically with depth as the rate of sulfate diffusion becomes less than the rate of sulfate reduction. The sulfate pool will be increasingly depleted in ${ }^{32} \mathrm{~S}$ and the isotopic value of late-forming pyrite may reflect closed-system conditions and be isotopically more positive.

Berner $(1969,1980)$ has suggested that pyrite nodule and layer growth involves locally high concentration of organic matter and migration of ferrous iron to the site of sulfate reduction. Under these conditions, pyrite nodules should show more positive $\delta^{34} \mathrm{~S}$ values from center to rim, reflecting accretionary growth in a system closed with respect to sulfate. The isotopic value of disseminated pyrite in the host rock should be more negative than or approximately the same as the nodule center, depending upon the concurrence of their formation.

Maynard (1980) found virtually no isotopic variation across a large pyrite nodule recovered from the Devonian Cleveland Shale. He suggested that the entire nodule

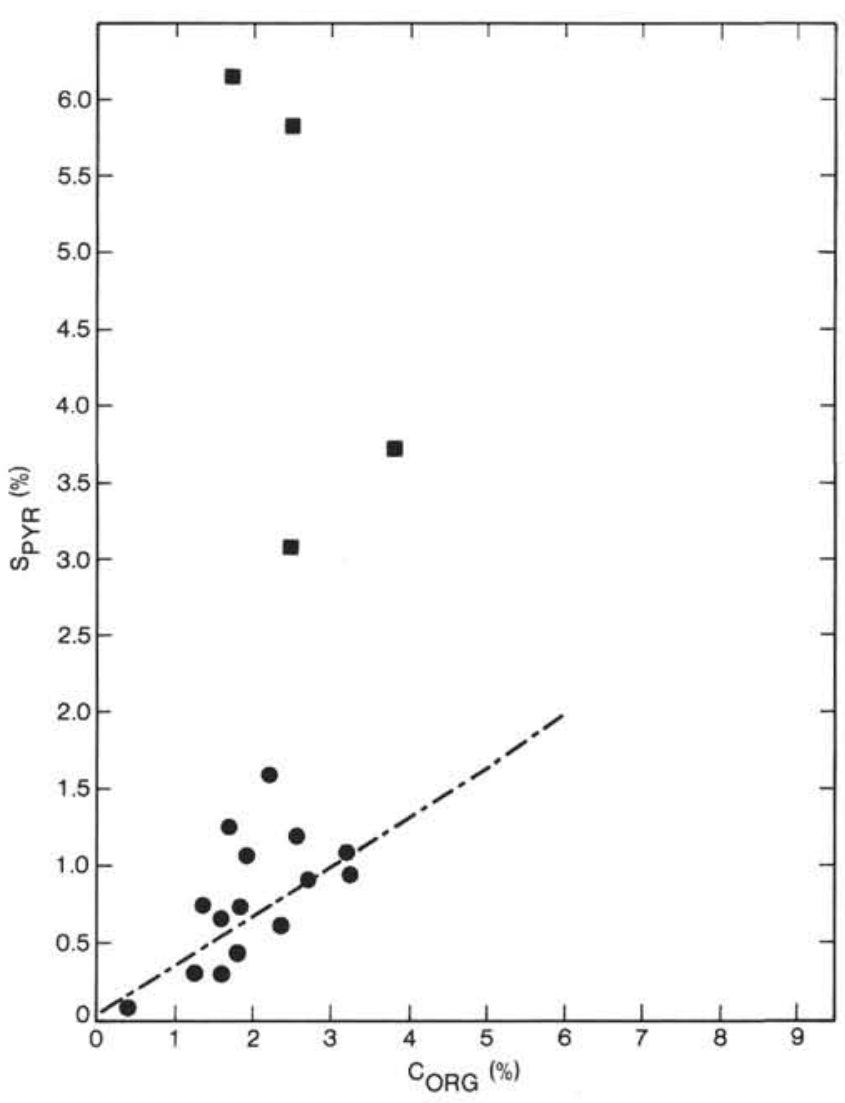

Figure 4. Relationship between disseminated pyritic sulfur and organic carbon for samples from Hole 603B analyzed in this study ( $\bullet$ ). The dashed line represents the modern "normal" marine line determined by Sweeney (1972). S/C ratios from rock immediately adjacent to nodules ( $\mathbf{E})$ lie above the line because of high concentrations of disseminated pyrite in these rocks.

formed from isotopically heavy sulfate late in the diagenetic history of the sediment. In his examination of Jurassic pyritiferous carbonate concretions, Raiswell (1982) found isotopic variation from center to margin, but approximately the same $\delta$ value for framboidal pyrite in the concretion centers and the host rock. Both concretions examined showed more positive isotopic values toward the concretion margin as well as a change to euhedral pyrite. Raiswell interpreted the euhedral pyrite as forming later than the framboidal pyrite.

Euhedral pyrite and framboidal pyrite possibly form via separate reaction pathways. Euhedral pyrite may form by direct precipitation from solution when pyrite is supersaturated, but metastable iron monosulfide intermediates mackinawite $\left(\mathrm{FeS}_{0.9}\right)$ and greigite $\left(\mathrm{Fe}_{3} \mathrm{~S}_{4}\right)$ are not (Sweeney and Kaplan, 1973; Goldhaber and Kaplan, 1974). Reaction between mackinawite and elemental sulfur may also lead to euhedral pyrite (Goldhaber and Kaplan, 1974; Rickard, 1975). Framboidal pyrite evidently forms only during the reaction of greigite with elemental sulfur (though mackinawite may form initially with greigite forming from it). As suggested by Goldhaber and Kaplan (1974) pH of the solution may determine whether mackinawite or pyrite is precipitated. Because of its lower solubility product, pyrite may be supersaturated at low $\mathrm{pH}$, whereas mackinawite may become undersat- 
urated. Under these conditions euhedral pyrite will precipitate directly from solution. From this, euhedral crusts on pyrite nodules would indicate different conditions of formation than framboidal pyrite in sediments.

Unlike Raiswell's (1982) concretions, pyrite nodules and layers from Hole 603B contain 75 to $100 \%$ pyrite with less than $25 \%$ carbonate. They often display euhedral crusts with massive interiors (Fig. 1). The $\delta^{34} \mathrm{~S}$ value of pyrite in nodules and layers is highly variable but generally more positive than disseminated pyrite in the surrounding rock, suggesting that it formed under closedsystem conditions.

Isotopic variation across large pyrite nodules did not show the expected simple pattern of more positive $\delta$ values toward the nodule rim. Samples across a nodule from Sample 603B-46-4, $14 \mathrm{~cm}$ showed a general trend toward the most positive isotopic values at the euhedral crust. However, the intermediate sample between center and rim had the most negative value (Fig. 3A). One of Raiswell's (1982) concretions showed a similar pattern, which he explained as being due to late euhedral overgrowths on the framboidal pyrite in the concretion center. Since the euhedral pyrite apparently formed later in a closedsulfate system, the isotopic value was more positive than the predominantly framboidal pyrite away from the center. There is no apparent morphologic difference, however, between the center and the interior of the nodule from Sample 603B-46-4, $14 \mathrm{~cm}$ to explain the isotopic variation. Isotopic variation across a second large pyrite nodule from Hole 603B exhibited a pattern opposite to that expected. Samples across a nodule from Sample 603B-66-2, $107 \mathrm{~cm}$ showed consistently less positive values from the center toward the nodule rim (Fig. 3B). These patterns would seem to imply that either isotopic fractionation changed with time as the nodules grew or that the "openness" of the sulfate system varied with time.

The complex isotopic record of pyrite nodules can be qualitatively interpreted assuming that $\Delta^{34} S$ is inversely proportional to the rate of sulfate reduction, which in turn exhibits first-order dependence on the concentration of metabolizable organic matter (Harrison and Thode, 1958; Kaplan and Rittenberg, 1964; Berner, 1978). Fluctuations in either the initial amount or the preservation of metabolizable organic matter would cause changes in the rate of sulfate reduction and, hence, in the extent of fractionation. Variations in the amount of metabolizable organic matter over time could be caused by changes in sedimentation rates and marine productivity. In addition, Berner and Westrich (1985) have demonstrated that organic matter can be added to sediment layers at depth by bioturbation. Fluctuations in the redox state of bottom waters and aerobic decomposition would alter the state of preservation of organic matter. The changing availability of organic matter with time could be reflected in the isotopic composition of a slowly accreting pyrite nodule. Futhermore, renewed bioturbation after a period with essentially no biological activity could "reopen" the system to seawater sulfate. The provision of seawater sulfate to a system that was previously closed with respect to sulfate could result in renewed growth of pyrite nodules. The later-forming sulfide would reflect isotopic values associated with open-system conditions, leading to a pattern of less positive $\delta^{34} \mathrm{~S}$ values from nodule center to rim.

\section{CONCLUSIONS}

Disseminated pyrite from Cretaceous organic-carbonrich rocks from Hole $603 \mathrm{~B}$ is 40 to $55 \% 0$ depleted in ${ }^{34} \mathrm{~S}$ relative to contemporaneous seawater sulfate. This fractionation is similar to that found by Goldhaber and Kaplan (1963) in the California Basins and represents sulfate reduction in a system with an unlimited sulfate reservoir (open-system), most likely just below the sediment/water interface. Sulfur/carbon ratios suggest that disseminated pyrite formation in Hole 603B during the Cretaceous occurred under oxygenated bottom water conditions and was limited by the availability of organic carbon.

Macroscopic pyrite probably forms as a late diagenetic product and is not representative of the environment of deposition and early diagenesis of the sediment in which it occurs. The results of a detailed study of large pyrite nodules suggest that growth history as reflected by isotopic composition is more complex than previously thought. Large pyrite nodules commonly occur in organic-carbon-rich rocks in Hole 603B and volumetrically represent a significant amount of reduced sulfur. The high content of pyritic sulfur in rocks immediately adjacent to nodules suggests local conditions that were especially conducive to pyrite formation. Although the nodule growth process is not fully understood, it seems likely that conditions necessary for nodule growth would include a relatively high concentration of both pyritizable iron and reactive organic carbon. Isotopic variations across large nodules could reflect heterogeneities in amount and preservation of metabolizable organic matter and/or variations in the "openness" of the sulfate system caused by fluctuations in bioturbation that could reflect fluctuations in the redox state of bottom waters.

\section{ACKNOWLEDGMENTS}

We would like to thank Michael A. Arthur, Walter E. Dean, and Donald L. Gautier for their valuable comments and assistance in preparation of the manuscript. This research was supported by NSF Grant OCE 82-18329.

\section{REFERENCES}

Berner, R. A., 1969. Migration of iron and sulfur within anaerobic sediments during early diagenesis. Am. J. Sci., 267:19-42.

1974. Kinetic models for the early diagenesis of nitrogen, sulfur, phosphorus and silicon in anoxic marine sediments. In Goldberg, E. D. (Ed.), The Sea, Vol. 5: New York (Wiley), 427-450. ,1978. Sulfate reduction and the rate of deposition of marine sediment. Earth Planet. Sci. Lett., 37:467-489.

, 1980. Early Diagenesis: A Theoretical Approach: Princeton (Princeton Univ. Press).

1982. Burial of organic carbon and pyrite sulfur in the modern ocean: its geochemical and environmental significance. Am. J. Sci., 282:451-473.

1984. Sedimentary pyrite formation: an update. Geochim. Cosmochim. Acta, 47:855-862.

Berner, R. A., and Raiswell, R., 1983. Burial of organic carbon and pyrite sulfur in sediments over Phanerozoic time: a new theory. Geochim. Cosmochim. Acta, 47:855-862.

Berner, R. A., and Westrich, J. T., 1985. Bioturbation and the diagenesis of carbon and sulfur. Am. J. Sci., 285:193-206. 
Bonnell, L. M., and Anderson, T. F., 1984. Sulfur isotopic variations in Cretaceous black and green shales. Geol. Soc. Am. Abstract with Programs, 16:449.

Claypool, G. E., Holser, W. T., Kaplan, I. R., Sakai, H., and Zak, I., 1980. The age curves of sulfur and oxygen in marine sulfate and their mutual interpretation. Chem. Geol., 28:199-260.

Gautier, D. L., Clayton, J. L., Leventhal, J. S., and Reddin, N. J., 1984. Origin and source-rock potential of the Sharon Springs Member of the Pierre Shale, Colorado and Kansas. In Woodward, J., Meisner F. F., and Clayton J. L. (Eds.), Hydrocarbon Source Rocks of the Greater Rocky Mountain Regions: Denver (Rocky Mountain Assoc. of Geol.), pp. 369-386.

Goldhaber, M. B., and Kaplan, I. R., 1974. The sulfur cycle. In Goldberg, E. D. (Ed.), The Sea, Vol. 5, Marine Chemistry: New York (Wiley), 469-655.

1975. Controls and consequences of sulfate reduction rates in recent marine sediments. Soil Sci., 119:42-55.

1980. Mechanisms of sulfur incorporation and isotope fractionation during early diagenesis in sediments of the Gulf of California. Mar. Chem., 9:95-143.

Goldhaber, M. B., Aller, R. C., Cochran, J. K., Rosenfield, J. K., Martens, C. S., and Berner, R. A., 1977. Sulfate reduction, diffusion and bioturbation in Long Island Sound: report of the FOAM group. Am. J. Sci., 277:193-237.

Harrison, A. G., and Thode, H. G., 1958. Mechanism of the bacterial reduction of sulfate from isotope fractionation studies. Faraday Soc. Trans, , 54:84-92.

Kaplan, I. R., Emery, K. O., and Rittenberg, S. C., 1963. The distribution and isotopic abundance of sulphur in recent marine sediments off southern California. Geochim. Cosmochim. Acta, 27: 297-331.

Kaplan, I. R., and Rittenberg, S. C., 1964. Microbiological fractionation of sulfur isotopes. J. Gen. Microbiol., 34:195-212.

Krouse, H. R., Brown, H. M., and Farquharson, R. B., 1977. Sulfur isotopic composition in DSDP Leg 37 cores. In Aumento, F., Melson, W. G., et al., Init. Repts. DSDP, 37: Washington (U.S. Govt. Printing Office), 621-623.
Leventhal, J. S., 1983. An interpretation of carbon and sulfur relationships in Black Sea sediments as indicators of environments of deposition. Geochim. Cosmochim. Acta, 47:133-138.

Maynard, J. B., 1980. Sulfur isotopes of iron sulfides in DevonianMississippian shales of the Appalachian Basin: control by rate of sedimentation. Am. J. Sci., 280:772-786.

Puchelt, H., and Hubberton, H. W., 1980. Preliminary results of sulfur isotope investigations on Deep Sea Drilling Project cores from Legs 52 and 53. In Donnelly, T. W., Francheteau. J., Bryan, W., Robinson, P., Flower, M., Salisbury, M., et al., Init. Repts. DSDP, 51, 52, 53, Pt. 2: Washington (U.S. Govt. Printing Office), 11451148.

Raiswell, R., 1982. Pyrite texture, isotopic composition and the availability of iron. Am. J. Sci., 282:1244-1263.

Rickard, D. T., 1975. Kinetics and mechanism of pyrite formation at low temperatures. Am. J. Sci., 275:635-652.

Sakai, H., 1968. Isotopic properties of sulfur compounds in hydrothermal processes. Geochem. J., 3:29-49.

Sweeney, R. E., 1972. Pyritization during diagenesis of marine sediments [Unpub. Ph.D. dissert.]. University of California, Los Angeles.

Sweeney, R. E., and Kaplan, I. R., 1973. Pyrite framboid formation: laboratory synthesis and marine sediments. Econ. Geol., 68:618634.

Westgate, L. M., and Anderson, T. F., 1982. Extraction of various forms of sulfur from coal and shale for stable isotope analysis. Anal. Chem., 54:2136-2139.

Westrich, J. T., 1983. The consequences and controls of bacterial sulfate reduction in marine sediments [Unpub. Ph.D. dissert.]. Yale University, New Haven.

Westrich, J. T., and Berner, R. A., 1984. The role of sedimentary organic matter in bacterial sulfate reduction: the G-model tested. Limnol. Oceanogr., 29:236-249.

Date of Initial Receipt: 4 April 1985 Date of Acceptance: 20 September 1985 